\section{Correspondence}

Check for updates

\section{OPEN ACCESS}

Address for Correspondence: Hae Il Cheong, MD, PhD

Department of Pediatrics, Seoul National

University Children's Hospital, Kidney

Research Institute, Medical Research Center, Seoul National University College of Medicine, 101 Daehak-ro, Jongno-gu, Seoul 03080,

Korea.

E-mail: cheonghi@snu.ac.kr

(c) 2019 The Korean Academy of Medical Sciences.

This is an Open Access article distributed under the terms of the Creative Commons Attribution Non-Commercial License (https:// creativecommons.org/licenses/by-nc/4.0/) which permits unrestricted non-commercial use, distribution, and reproduction in any medium, provided the original work is properly cited.

ORCID iDs

Mi Young Kim (D)

https://orcid.org/0000-0002-2574-5282 Ji Hyun Kim (D)

https://orcid.org/0000-0001-8477-0157

Myung Hyun Cho (D)

https://orcid.org/0000-0002-3237-3173

Young Hun Choi (D)

https://orcid.org/0000-0002-1842-9062 Seong Heon Kim (D)

https://orcid.org/0000-0001-8003-3010

Young Jae Im (1)

https://orcid.org/0000-0002-8285-483X Kwanjin Park (iD)

https://orcid.org/0000-0002-8926-3047

Hee Gyung Kang (D)

https://orcid.org/0000-0001-8323-5320

Jong-Hee Chae (D)

https://orcid.org/0000-0002-9162-0138

Hae Il Cheong (D)

https://orcid.org/0000-0001-7556-1265

\title{
Erratum: Correction of Error in Result: Urological Problems in Patients with Menkes Disease
}

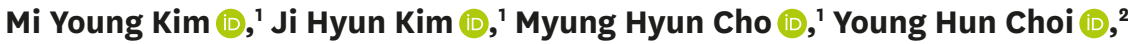 \\ Seong Heon Kim $\left(\mathbb{1},{ }^{3}\right.$ Young Jae Im $\left(\mathbb{0},{ }^{4}\right.$ Kwanjin Park $\left(\mathbb{1},{ }^{4}\right.$ Hee Gyung Kang $\left(\mathbb{1},{ }^{1}\right.$ \\ Jong-Hee Chae $\mathbb{D}^{\circ},{ }^{5}$ and Hae Il Cheong $(\mathbb{1})^{1,6}$
}

\begin{abstract}
'Department of Pediatrics, Seoul National University Children's Hospital, Seoul, Korea ${ }^{2}$ Department of Radiology, Seoul National University Children's Hospital, Seoul, Korea ${ }^{3}$ Department of Pediatrics, Pusan National University Children's Hospital, Yangsan, Korea ${ }^{4}$ Division of Pediatric Urology, Seoul National University Children's Hospital, Seoul, Korea ${ }^{5}$ Department of Pediatrics, Pediatric Clinical Neuroscience Center, Seoul National University Children's Hospital, Seoul, Korea

${ }^{6}$ Kidney Research Institute, Medical Research Center, Seoul National University College of Medicine, Seoul, Korea
\end{abstract} - This corrects the article "Urological Problems in Patients with Menkes Disease" in volume 34,
number 1, e4.

To the Editor:

The authors regret that there was an important error in the results in Table 1; the ATP7A mutations detected in Patients 2 and 14 were incorrectly noted.

The corrected notation of the mutations is as follows:

1) The c.1303delA (p.A434Qfs ${ }^{\star} 2$ ) mutation detected in Patient 2 should be changed to c.1303delA (p.Ile435 ).

2) Patient 14 had a previously known mutation, i.e., c.3257delA (p.His1086Profs ${ }^{\star} 3$ ); c.4048G >A (p.E1350K) is a common single nucleotide polymorphism detected together with the mutation.

Accordingly, corrections in the main text are needed as follows:

1) In the first paragraph of "Mutational analyses of the ATP7A gene" on page 3, "2 missense mutations," "2 frame-shifting short deletions," and "Seven mutations were novel" should be changed to " 1 missense mutation," " 3 frame-shifting short deletions nonsense mutations," and "Six mutations were novel."

2) The last sentence in the first paragraph of the "Discussion" section, "Patient 14 in our study had a missense mutation in ATP7A," should be changed to "Patient 14 in our study had a frame-shifting short deletion mutation in ATP7A." 